AL-IQTISHOD: Jurnal Pemikiran dan Penelitian Ekonomi Islam

E-ISSN: 2407-6600 P-ISSN: 2745-85I2

Volume I0 Issue I Januari 2022 | Page: 079-095

DOI: https://doi.org/I0.37812/aliqtishod

TINJAUAN EKONOMI ISLAM PADA TRADISI BHUBUWENDI MADURA (Studi kasus Bhubuwen di Desa Sukolilo Timur Labang Bangkalan)

\title{
Muaddin
}

Universitas Islam Negeri (UIN) Surabaya

muaddzinhasyim@gmail.com

\section{Nur Aini}

STAI Al-Azhar Menganti Gresik

nurainichymt@gmail.com

\begin{abstract}
Village communities cannot be separated from all life activities in the village with various social traditions, one of which is the bhubuwen tradition, namely helping each other financially. This research was conducted to answer how the bhubuwen tradition in the perspective of Islamic economics. The type of research used in this research is qualitative research, namely by analyzing and describing how the bhubuwen tradition actually occurs in the East Sukolilo community. Data collection techniques using interviews and documentation. Data analysis used qualitative data analysis, namely searching and systematically compiling data obtained from interviews, field notes and documentation by making patterns, selecting the important ones and drawing conclusions, finally testing the validity of the data with data triangulation techniques. This study concludes that the bhubuwen tradition in East Sukolilo village is the practice of donating money in to'oto' and remoh events, the donation is in the form of a debt that must be returned in the same size. Whereas in the Islamic perspective, the contract used is the qardh contract because the elements contained in the qardh are in accordance with the elements contained in the bhubuwen tradition.
\end{abstract}

Keywords: Qardh, Bhubuwen

Abstrak: Masyarakat desa tidak bisa lepas dari semua kegiatan kehidupan di desa dengan berbagai macam tradisi bermasyarakat salah satunya adalah tradisi bhubuwen yaitu saling bantu membantu dalam hal finansial. Penelitian ini dilakukan untuk menjawab bagaimana tradisi bhubuwen dalam prespektif ekonomi Islam. Jenis penelitian yang digunakan dalam penelitian ini adalah penelitian kualitatif yaitu dengan menganalisis dan mendeskripsikan bagaimana sebenarnya tradisi bhubuwen yang terjadi dalam masyarakat Sukolilo Timur. Teknik pengumpulan data menggunakan metode wawancara dan dokumentasi. Analisis data menggunakan analisis data kualitatif yaitu mencari dan menyusun secara sistematis data yang diperoleh dari hasil wawancara, catatan lapangan dan dokumentasi dengan cara membuat pola, memilih yang penting serta menarik kesimpulan, terakhir dilakukan uji keabsahan data dengan teknik triangulasi data. Penelitian ini menyimpulkan bahwa tradisi bhubuwen di desa Sukolilo Timur adalah praktek sumbang menyumbang uang dalam acara to 'oto' dan remoh, sumbangan tersebut berupa hutang yang harus dikembalikan dengan ukuran yang sama. Sedangkan dalam prespektif Islam akad yang digunakan adalah akad qardh karena unsur-unsur yang terdapat dalam qardh sudah sesuai dengan unsur yang terdapat dalam tradisi bhubuwen.

Kata Kunci: Qardh, Bhubuwen 



\section{A. Pendahuluan}

Madura adalah salah satu daerah sebelah timur pulau jawa yang mempunyai beranekaragam adat istiadat dan kebudayaan yang sangat melekat pada kebiasaan masyarakat. Desa merupakan tempat dimana hubungan ekonomi, hubungan sosial dan kekerabatan menjadi kesatuan adat yang sangat erat. Sehingga orang desa hidup dengan saling membantu satu sama lain dari berbagai segi seperi tenaga, ataupun materi.

Masyarakat desa tidak bisa lepas dari semua kegiatan kehidupan di desa dengan berbagai macam tradisi bermasyarakat salah satunya adalah tradisi bhubuwen yaitu saling bantu membantu dalam hal finansial. Tradisi bhubuwen atau buwuh adalah sumbang menyumbang dalam acara to'oto' (hajatan pernikahan, sunatan ataupun tanpa hajatan). Tradisi ini dapat menghubungkan individu satu dengan individu lainnya dalam suatu kelompok masyarakat. Akibatnya, satu individu akan sulit untuk lepas selama individu tersebut tetap tinggal dalam suatu kelompok masyarakat yang berpegang teguh pada tradisi. Sehingga tradisi ini digunakan sebagai jaminan sosial masyarakat. Dalam Kamus Besar Bahasa Indonesia (KBBI) kata buwuh berarti uang atau barang yang dibawa oleh tamu undangan untuk diberikan kepada tuan rumah sebagai sumbangan dari suatu upacara atau pesta. ${ }^{I}$ Sehingga, pada dasarnya tradisi buwuh berfungsi sebagai sumbangan yang dibawa oleh tamu undangan untuk membantu pihak yang mengadakan pesta (seperti pesta pernikahan).

Aktifitas bhubuwen di masyarakat secara umum diterima masyarakat, maka bisa dikatakan masih berada pada koridor Islam yang dinilai baik, sebab dalam tolong menolong atau gotong royong antar sesama telah dianjurkan dan digariskan dalam alQur'an. Tradisi bhubuwen di Desa Sukolilo Timur terdapat dalam acara to'oto, dan sebenarnya sumbangan dalam acara to'oto' tidak hanya berupa uang tetapi juga berupa barang. Disini letak perbedaan buwuh dijawa dan di Desa Sukolilo Timur, di jawa buwuh

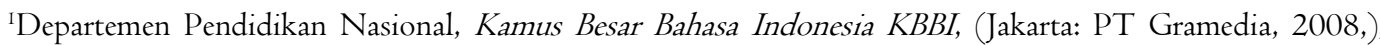
230

Volume. IO/No. I/Januari 2022 A1-Iqtishod|79 
Tinjauan Ekonomi Islam Pada ...

itu meliputi uang dan barang tapi jika di Desa Sukolilo Timur buwuh itu hanya berupa uang.

Kepastian dan kejelasan akad sangat penting untuk menentukan hukum sesuai dengan akad yang digunakan, hukum dalam akad bemanfaat untuk melindungi kedua belah pihak áqidain. Maka jika salah dalam menentukan sebuah akad akan berakibat pada penentuan hukumnya juga yang akhirnya berimplikasi pada kerugian di salah satu pihak. Selain akad penulis juga menekankan bagaimana tata cara pencatatan bhubuwen apakah sudah sesuai dengan anjuran pencatatan dalam ekonomi Islam.

Dari pemaparan di atas penulis akan membahas mengenai kejelasan akad dan prosedur pencatatan dalam tradisi bhubuwen yang terjadi di desa Sukolilo Timur Kecamatan Labang Kabupaten Bangkalan Madura. Penelitian ini dilakukan dengan sistematis dan obyektif sehingga diperoleh hasil bagaimana praktek bhubuwen dan akad yang diterapkan dari perspektif ekonomi Islam yang terjadi dimasyarakat desa Sukolilo Timur, Kecamatan Labang, Kabupaten Bangkalan Madura.

\section{B. Kajian Pustaka}

Tradisi adalah kebiasaan atau adat istiadat masyarakat pada suatu daerah atau golongan baik berupa perbuatan maupun perkataan. ${ }^{2}$ Namun tradisi memiliki tempat khusus dalam penetapan hukum Islam, tradisi atau adat dalam Islam lebih dikenal dengan urf dan menjadi dalil ketujuh dalam penetapan suatu hukum. Para ulama sepakat menolak urf fasid atau adat kebiasaan yang rusak untuk dijadikan landasan hukum. ${ }^{3}$ Ulama hanya menerima urf yang benar yakni suatu kebiasaan yang dilakukan manusia tetapi tidak menentang dalil syara', tidak merubah suatu yang haram menjadi halal, tidak membatalkan yang wajib dan menolak urf yang rusak. Yaitu, adat yang dilakukan oleh manusia tetapi bertentangan dengan syara' menghalalkan yang haram atau membatalkan yang wajib. ${ }^{4}$

${ }^{2}$ Satria Effendi dan M.Zein, Ushul Fiqh, (Jakarta: Kencana, 2005), I54.

${ }^{3}$ Ibid, hlm. I55.

${ }^{4}$ Abdul Wahab Khallaf, Ilmu Ushul al-Fiqh Kaidah Hukum Islam, (Jakarta: Pustaka Amani, 2003), I 7.

80| Al-Iqtishod Volume. IO/No. I/Januari 2022 
Akad

Akad merupakan salah satu cara untuk memperoleh harta dalam syari'at Islam yang banyak digunakan dalam kehidupan sehari-hari karena akad adalah cara yang diridhoi Allah SWT. Perjanjian dalam akad merupakan perjanjian kedua belah pihak untuk mengikatkan diri tentang perbuatan yang akan dilakukan dalam suatu hal khusus. Akad ini diwujudkan pertama, dalam ijab kabul. Kedua, sesuai dengan kehendak syariat. Ketiga, adanya akibat hukum pada objek perikatan. ${ }^{5}$ Setiap akad mencakup tiga hal yaitu perjanjian, persetujuan dua buah perjanjian atau lebih dan perikatan. Jadi definisi akad adalah pertalian antara ijab dan kabul yang dibenarkan oleh syara'. ${ }^{6}$

\section{Qardh}

Secara etimologis qardh merupakan bentuk masdar dari qaradha as-Syai'-yaqridhu, yang berarti dia memutuskannya. Qardh adalah bentuk masdar yang berarti memutuskan. Dikatakan qaradha as-Syai' bi al-Miqradh, atau memutuskan sesuatu dengan gunting. Qardh adalah sesuatu yang diberikan oleh pemilik untuk dibayar. ${ }^{7}$ Adapun arti qardh secara terminologis adalah memberikan harta kepada orang yang akan memanfaatkannya dan mngembalikan gantinya dikemudian hari ${ }^{8}$

\section{Hibah}

Hibah secara bahasa berasal dari kata wahaba, yang berarti lewat dari satu tangan ke tangan yang lain atau dengan kata lain kesadaran untuk melakukan kebaikan atau diambil dari kata hubub ar-Rih (angin yang menghembus) atau ibra (membebaskan utang). ${ }^{9}$

\section{Metode Penelitian}

Penelitian ini bertujuan menjawab permasalahan yang ada, pertama, bagaimana konsep pelaksanaan tradisi bhubuwen di desa Sukolilo Timur, yang kedua bagaimana

${ }^{5}$ Mandani, Fiqih Ekonomi Syariah Fiqih Muamalah, (Jakarta: Kencana, 2012), 7I.

${ }^{6}$ Gemala Dewi. dkk, Hukum Perikatan Islam di Indonesia, (Jakarta: Kencana, 2005), 47.

${ }^{7}$ Mandani, Fiqih Ekonomi Syariah Fiqh Muamalah, (Jakarta: Kencana, 2012), 333.

${ }^{8}$ Abdullah bin Muhammad ath-Thayyar, Ensiklopedi Fiqh Muamalah dalam Pandangan 4 Mazdhab, (Yogyakarta: Maktabah Al-Hanif, 2009), I53.

${ }^{9}$ Mandani, Fiqih Ekonomi Syariah Fiqh Muamalah, (Jakarta: Kencana, 2012), 342.

Volume. IO/No. I/Januari 2022 Al-Iqtishod |8I 
Tinjauan Ekonomi Islam Pada ...

manajemen dari tradisi bhubuwen di desa Sukolilo Timur, serta yang ketiga bagaimana tradisi bhubuwen dalam prespektif manajemen Islam. Metode penelitian yang digunakan dalam penelitian ini yaitu deskriptif kualitatif, dimana penelitian akan menganalisis serta mendeskripsikan bagaimana tradisi bhubuwen yang terjadi di masyarakat Sukolilo Timur dengan prosedur yang menghasilkan data deskriptif berupa kata-kata tertulis maupun lisan dari objek penelitan yaitu orang orang dan perilaku yang diamati.

Jenis penelitian yang digunakan dalam penelitian ini adalah penelitian kualitatif, yakni penelitian yang dilakukan untuk memahami fenomena dari objek yang diteliti. Dalam penelitian kualitatif, pengumpulan data bukan berdasarkan teori, namun berdasarkan fakta-fakta yang ditemui oleh peneliti di lapangan, sedangkan sifat analisis data bersifat induktif yaitu analisis yang dilakukan berdasarkan fakta di lapangan.

Teknik pengumpulan data dalam penelitian ini menggunakan metode wawancara dan dokumentasi, dimana wawancara merupakan percakapan antara seseorang yang membutuhkan informasi dengan seseorang (informan) yang diasumsikan memiliki informasi yang penting akan suatu objek atau permasalahan, sedangkan dokumentasi merupakan metode yang dilakukan dengan menelusuri data-data historis, baik melalui buku ataupun catatan terkait dengan permasalahan yang diteliti.

Metode analisis data yang dilakukan dalam penelitian mencari dan menyusun secara sistematis data yang telah diperoleh melalui wawancara dan dokumentasi, selanjutnya menganalisis data menggunakan pola, mempertimbangkan hal penting yang selanjutnya dipelajari serta disimpulkan agar dapat dipahami oleh diri-sendiri dan orang lain. Peneliti menggunakan cara deduktif kualitatif untuk menganalisa dan menggambarkan keadaan yang terjadi di masyarakat, selanjutnya dianalisa dengan pola berfikir dari suatu kaidah atau norma yang bersifat umum menjadi kenyataan yang bersifat khusus. 
Muaddin, Nur Aini

\section{Hasil dan Pembahasan}

\section{Tradisi Bhubuwen di Desa Sukolilo Timur}

Bhubuwen atau bhubu adalah istilah kata dalam bahasa Madura untuk mengartikan buwuh atau buwuhan dalam bahasa Indonesia.Tradisi sumbang menyumbang atau bhubuwen di masyarakat Madura khususnya Desa Sukolilo Timur tidak hanya pada acara pernikahan, sunatan ataupun hajatan lainnya yang umumnya dilakukan oleh masyarakat di berbagai daerah di Madura tapi di desa ini praktek bhubuwen juga bisa diadakan diluar acara, jadi jika seseorang ingin mengadakan bhubuwen maka dia harus mengadakan acara to 'oto' terlebih dahulu. Nama acaranya adalah to'oto' sedangkan praktek sumbang menyumbang dalam acara tersebut dinamakan bhubuwen. ${ }^{10}$

Dalam prakteknya pada saat seseorang ingin mengadakan bhubuwen ada proses yang harus dilaksanakan pertama proses persiapan acara hajatan berupa pernikahan dan remoh/to 'oto' dan yang kedua proses persiapan bhubuwen, karena bhubuwen adalah praktek transaksi keuangan yang terdapat dalam acara pernikahan, tidak hanya pada acara tertentu saja, bhubuwen juga bisa diadakan meskipun tanpa ada sebab hajatan seperti pernikahan. Maka nanti akan diklasifikasikan menjadi bhubuwen dengan sebab dan bhubuwen tanpa sebab. Seseorang tidak harus menunggu menikahkan anaknya, bahkan akan jadi masalah jika belum memiliki anak dan tidak bisa mengadakan bhubuwen, maka dari itu mengadakan bhubuwen dapat dilakukan meskipun tanpa sebab apapun.

Untuk mempersiapkan bhubuwen seseorang haruslah terlebih dahulu berembuk dengan ketua to oto' Desa Sukolilo Timur untuk menentukan waktu, juru tulis, juru pungut dan juga undangan. Berikutnya penulis akan menjelaskan bagaimana alur kordinasi dalam persiapan acara to'oto' dan juga persiapan yang dibutuhkan dan yang harus dilakukan untuk mengadakan bhubuwen adalah pertama orang yang ingin berhajat berkordinasi dengan ketua bhubuwan dan kepala desa kemudian ke agen

${ }^{\text {I0}} \mathrm{H}$. Kholil, Wawancara, Bangkalan 3 Februari 2016

Volume. IO/No. I/Januari 2022 Al-Iqtishod| 83 
Tinjauan Ekonomi Islam Pada...

buwuh. Bhubuwen dibedakan antara laki-laki dan perempuan yang disebut lake'an (laki-laki) dan bine'an (perempuan), suami maupun istri bisa buwuh apalagi jika nanti dia akan mengadakan to'oto' maka itu sebagai utang yang harus dikembalikan dengan jumlah atau takaran yang sama, dalam sosial ekonomi dikenal dengan istilah resiprositas yaitu efek timbal balik dari adanya sumbangan yang disumbangkan dengan harapan akan mendapatkan hal yang sama jika penyumbang mengadakan bhubuwen juga.

Dalam mengadakan remoh atau to'oto' ada waktu waktu tertentu yang diperbolehkan, peraturan mengenai waktu pelaksanaan acara tersebut telah desepakati oleh masyarakat dari dulu, mengikuti kalender islam (tahun hijriyah) terdapat beberapa bulan yang tidak diperbolehkan mengadakan remoh atau to'oto' yaitu bulan Ramadhan dan bulan Rabiul Awal. Sedangkan bulan-bulan yang baik untuk mengadakan acara hajatan tersebut selain dua bulan diatas. Untuk acara pernikahan paling sering diadakan di bulan Dzulhijjah, bulan Rabiul Akhir (Tsani), bulan Rajab dan bulan Sya'ban. Sedangkan untuk acara to'oto' biasa dilaksanakan pada bulan Syawal, bulan Dzulqa'dah, bulan Muharram, bulan Shafar, bulan Jumadil Ula (Awal) dan juga bulan Jumadil Akhir (Tsani).

Sudah diketahui bahwa bhubuwen adalah praktek sumbang-menyumbang dengan memberikan pinjaman yang terjadi di masyarakat. Uang yang disumbangkan pada waktu pengembaliannya harus dengan jumlah, nilai atau takaran dan timbangan yang sama jika nantinya penyumbang mengadakan acara serupa. Dalam sumbangan itu tidak di tentukan nilainya, ada perbedaan nilai setiap warga dalam sumbangan dilihat dari siapa yang mengadakan to'oto', jika itu masih saudara biasanya nilainya lebih tinggi dari pada buwuh ke orang lain, tapi tidak semuanya dilihat juga dari buku catatan bhubuwennya, biasanya orang berpenghasilan besar buwuhnya juga besar.

Uang adalah benda utama yang dibutuhkan setiap orang, begitu juga dalam tradisi bhubuwen sehingga objek bhubuwen yang nyata berupa uang, dalam artian sudah dapat terlihat nilainya dengan jelas dibandingkan dengan barang karena 
memang barang dinilai dengan uang, bukan uang dinilai dengan barang. Di Desa Sukolilo Timur abhubu pesse (nyumbang uang) terdapat perbedaan nominal yang disumbangkan antara tamu laki-laki dan tamu perempuan, perbedaan ini berimplikasi pada total uang yang masuk secara keseluruhan. Biasanya nominal buwuh tamu Perempuan lebih kecil dari pada tamu laki-laki.

Sebelum mengadakan acara to'oto' pihak yang akan mengadakan hajatan harus melapor kepada pihak kepala desa terlebih dahulu, dengan tujuan untuk membuat izin keramaian (mengumpulkan masyarakat banyak). Wajib melakukan permohonan izin terlebih dahulu karena mengumpulkan masyarakat banyak, jika tidak mengantongi izin maka bisa saja acara tersebut dihentikan oleh pihak muspika. Alur perizinan acara to oto' pertama kepada kepala desa, kedua kecamatan, ketiga Koramil dan terakhir Polsek.

Proses penyerahan bhubuwen dapat secara langsung diserakan kepada juru tulis atau menitipkan kepada agen dan kelompok, warga yang menyerahkan sumbangannya dengan datang langsung biasanya berasal dari luar daerah misalnya dari Surabaya atau daerah yang jauh, uang bhubuwen yang diserahkan terlebih dahulu dimasukkan kedalam amplop dengan keterangan nama dan alamat, tapi jika masih Penyerahan uang buwuh melewati agen atau kelompok akan dikumpulkan terlebih dahulu dengan catatan nama-nama anggota dan juga nominal uang tersebut. Penyerahan dengan sistem ini akan mempermudah juru tulis untuk mencatat uang buwuh tanpa menanyakan satu persatu tamu yang datang, ketua agen hanya menyerahkan uang dan catatan yang sudah disiapkan sebelumnya. ${ }^{\mathrm{II}}$

Pencatatan bhubuwen dalam tradisi ini menjadi suatu keharusan karena akan menjadi bukti utang piutang antara orang yang buwuh dan pemilik hajatan, disamping catatan pemilik hajatan begitu juga orang yang buwuh harus memilik catatan untuk jaga jaga jika nantinya terjadi komplain. Setiap kampung di Desa Sukolilo Timur memiliki juru tulis masing masing. Jika kampung A mengadakan bhubuwen maka juru

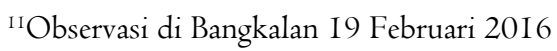

Volume. I0/No. I/Januari 2022 A1-Iqtishod | 85 
Tinjauan Ekonomi Islam Pada...

tulis dan juru pungutnya dari kampung tersebut tetapi tidak menutup kemungkinan akan menggunakan juru tulis atau juru pungut dari kampung lain karena itu tergantung keputusan tuan rumah dan juga kebijakan ketua sendiri, juru pungut dan juru tulis di setiap kampung sebenarnya tetap menjadi milik desa. Tapi agar mempermudah manajemen, maka dibagi menjadi dua yaitu barat dan timur. Juru tulis dan juru pungut bhubuwen di Desa Sukolilo Timur bersifat khusus yang memang ditunjuk langsung oleh ketua bhubuwen dan juga sesepuh desa. Jadi jika mengadakan bhubuwen tidak boleh menyuruh orang untuk menjadi juru tulis karena itu sudah menjadi kesepakatan dan memang dipilih masyarakat. Maka haruslah memilih orang yang ahli dan pengalaman menjadi juru tulis bhubuwen. Seseorang yang ditunjuk menjadi juru tulis haruslah yang berpengalaman dan sebelumnya memang telah dipilih oleh ketua bhubuwen dan juga sesepuh desa. Namun dalam menetapkan seseorang menjadi juru tulis bukanlah keputusan sepihak tapi menjadi keputusan bersama atau sudah didiskusikan bersama sebelumnya.

Dalam kehidupan pasti ada permasalahan permasalahan baik dalam sebuah organisasi formal maupun non formal, begitu juga dengan apa yang terjadi dalam tradisi bhubuwen di Desa Sukolilo Timur tidak akan luput dari konflik dan permasalahan yang datang dari personal masing-masing, baik permasalahan yang memang dibuat atau permasalahan yang murni datangnya. Konflik dalam tradisi bhubuwen tidak jauh dari permasalahan uang dan pembayaran buwuh. Misalnya, uang buwuh tidak kembali maksudnya orang yang dibuwuhi tidak datang atau datang tapi uang yang diberikan berbeda nominal. Permasalahan ini bisa diselesaikan antara kelompok orang-orang yang bermasalah tersebut melewati perantara ketua. Tapi terlebih dahulu harus ada komplain dari pihak yang bermasalah.

Selama ada bukti yang jelas maka permasalahan yang berkenaan dengan kesalahan pencatatan akan mudah diselesaikan, di samping itu jika uang yang dulu disumbangkan ke orang lain pada waktu orang tesebut punya hajatan tetapi ketika si penyumbang mengadakan bhubuwen dan yang disumbang tidak buwuh atau tidak 
menyerahkan hutangnya maka itu menjadi masalah, pada masyarakat dikenal dengan settad yaitu penagihan uang yang tidak kembali "lok deteng". Dalam penagihan utang buwuh sebenarnya tergantung pada tuan rumah yang punya hajatan, apakah dia mau menagih piutangnya atau mengikhlaskannya. Jika ingin maka harus menghubungi ketua terlebih dahulu bukan langsung kepada orang yang tidak mengembalikan buwuh. Karena memang sebenarnya hutang piutang dalam buwuh itu harus dibayar, seluruh masyarakat Desa Sukolilo Timur sepakat keharusan membayar hutang buwuh, kecuali jika orang yang berpiutang meninggal karena buwuh itu tidak diwariskan maka amsyarakat sepakat untuk mengikhlaskannya. Kesepakatan pembebasan hutang buwuh berlaku ketika penyumbang telah meninggal dunia karena memang tujuan sebenarnya dari to'oto' adalah mencari teman saling tolong menolong, maka dapat di ambil kesimpulan bahwa orang yang ikut bhubuwen sudah sepakat dan menyadari kesepakatan tersebut.

\section{Tradisi Bhubuwen di Desa Sukolilo Timur Labang Bangkalan dalam Prespektif Ekonomi Islam}

Dari penjelasan perihal praktek tradisi bhubuwen di Desa Sukolilo Timur Labang Bangkalan dapat dilihat bahwa tradisi ini adalah termasuk tradisi tolong menolong antar anggota masyarakat dalam hal finansial, persiapan prosesi tradisi ini juga membutuhkan bantuan tenaga maupun pikiran. Penulis melihat bahwa pada tradisi ini tidak hanya berdasarkan keikhlasan semata tetapi buwuh itu seperti halnya dengan qardh, qardh sendiri adalah akad tabarru' atau akad sosial yang pemgembaliannya harus sesuai dengan barang yang dihutangkan, misalnya hutang uang IO ribu maka harus diganti dengan IO ribu juga. Karena hutang buwuh kepada orang harus mengganti sesuai dengan nominal buwuh yang di berikan.

Akad qardh dalam tradisi ini dapat beralih menjadi akad hibah dengan syarat orang yang buwuh telah meninggal dunia. Peralihan tersebut berdasarkan praktek bhubuwen bahwa orang yang meninggal hutang buwuhnya akan di ikhlaskan sesuai 
Tinjauan Ekonomi Islam Pada ...

dengan kesepakatan anggota to oto'. Tujuan utama bhubuwen adalah membantu oleh karena itu hutang buwuh tidak diwariskan melainkan diikhlaskan. Penetapan peralihan akad tersebut berdasarkan hukum urf yaitu kesepakatan anggota to'oto' untuk mengikhlaskan hutang, selama orang yang buwuh masih hidup maka akad qardh akan tetap berlaku. Sebelum orang yang buwuh meninggal maka keharusan membayar hutang tetap menjadi kewajiban setiap anggota to'oto'. Kewajiban membayar hutang buwuh sesuai dengan nominal hutangnya, tidak boleh kurang, jika hutangnya kurang maka akan ditagih, penagihannya dengan dengan cara kekeluargaan melalui ketua, ketua berfungsi sebagai penjamin bhubuwen jika terjadi konflik. Tetapi jika pembayaran hutangnya lebih maka itu tidak dinamakan tambahan sepertihalnya riba, tambahan itu akan dihitung hutang. Misalnya, Bapak Ghani memiliki hutang buwuh kepada Bapak Bidin sebesar 20 ribu, tetapi Bapak Ghani membayar 40 ribu, maka tambahan 20 ribu dari hutang Bapak Ghani akan dihitung sebagai hutang lagi dalam artian Bapak Ghani memberi hutang buwuh kepada Bapak Bidin. Dalam istilah bhubuwen dinamakan ngompang. Jadi dalam tradisi bhubuwen tidak ada praktek riba. Karena setiap tambahan yang dibayarkan atas pembayaran hutang buwuh akan dicatat sebagai hutang kembali.

Jika dilihat dari tata cara tradisi bhubuwen dalam memberi buwuh maupun membayar buwuh maka dapat dilihat bahwa tradisi ini merupakan praktek hutang piutang. Penulis berpendapat demikian karena jika tidak termasuk hutang mengapa harus ada pencatatan dan mengapa juga harus ada penagihan buwuh. Ini sudah jelas mengindikasikan penggunaan akad qardh dalam tradisi bhubuwen. Penulis akan menjelaskan mengapa tradisi ini menggunakan akad qardh dan apa perbedaannya dengan akad yang lain sehingga praktek ini lebih tepat dikatakan sebagai praktek hutang bukannya hibah, wadi'ah ataupun akad lainnya.

Praktek tradisi bhubuwen jika disamakan dengan hibah sangat berbeda sekali bahkan bertolak belakang dilihat dari pengertiannya hibah adalah memberikan barang 
dengan tidak ada takarannya dan tidak ada sebabnya pula. ${ }^{\mathrm{I} 2}$ semata-mata untuk mendekatkan diri kepada Allah SWT dimana orang yang diberi bebas menggunakan harta tersebut karena memang harta itu menjadi hak milik orang yang diberi hibah, harta hibah adalah harta pemberian yang tidak perlu diganti. Jika disamakan dengan bhubuwen sangat tidak relevan dari tujuan maupun makna, bhubuwen tujuannya adalah membantu dengan memeberikan pinjaman yang harus dikembalikan nanti pada waktunya, pinjaman ini bersifat hutang karena ada kewajiban mengembalikan begitu juga pengembaliannya harus sama dari nilai dan jumlahnya. Jadi praktek bhubuwen bukan termasuk dalam akad hibah yang tujuannya adalah memberikan harta tanpa ganti rugi atau pemberian dengan ikhlas karena ingin mendapat rahmat Allah semata. Akad hibah akan berlaku pada praktek bhubuwen ketika orang yang buwuh meninggal dunia sesuai hukum urf.

Praktek tradisi bhubuwen juga tidak bisa disamakan dengan akan wadiah yaitu akad titipan baik wadi'ahamanah maupun wadiah yad dhamanah karena dalam praktek akad wadi'ah harta titipan memang dititipkan baik itu untuk dikelola atau tidak sedangkan dalam bhubuwen harta tidak dititipkan melainkan diserahkan dengan hutang dan jangka waktu pengembalian, dan penerima buwuh bebas menggunakan harta tersebut tanpa adanya izin dari orang yang buwuh.

Dalam wadiah amanah orang yang menerima harta titipan tidak boleh menggunakan harta tersebut karena dia hanya diberikan amanah untuk mejaganya saja tanpa mengelolanya sedangkan dalam wadiah yad dhamanah orang yang menerima barang titipan boleh memanfaatkan harta tersebut seperti yang dipraktekkan dalam perbankan syariah, wadiah yadh dhamanah memiliki kemiripan dengan qardh, barangnya sama sama digunakan oleh orang yang berhutang dan orang yang diberi titipan, yang membedakan adalah hak milik. Jika dalam wadiah hak milik barang tetap dimiliki oleh orang yang menitipkan tetapi dalam qardh hak milik barang telah berpindah kepada orang yang berhutang, karena akad qardh adalah akad pemberian

\footnotetext{
${ }^{12}$ Sulaiman Rasjid, Fiqh Islam Hukum Fiqh Islam, (Bandung: Sinar Baru Algensindo, 20I I), 327
}

Volume. I0/No. I/Januari 2022 A1-Iqtishod | 89 
Tinjauan Ekonomi Islam Pada ...

kepemilikan. ${ }^{13}$ Selain itu dalam wadia'h yad dhamanah orang yang menerima titipan boleh menggunakannya selagi ada izin dari pemilik harta, tetapi jika qardh orang yang berhutang tidak memerlukan izin pemberi hutang.

Penulis menetapkan bahwa ptaktek tradisi bhubuwen di Desa Sukolilo Timur Kecamatan Labang Kabupaten Bangkalan menggunakan akad qardh (utang piutang). Meskipun dalam prakteknya penyerahan buwuh itu tidak dengan jelas menggunakan qardh pada saat ijab kabul tapi dari esensinya dapat dilihat apakah itu termasuk akad qardh atau bukan, maksud dari suatu akan tidak hanya tercermin pada satu shigah saja hanya perkataan melainkan juga dari perbuatan, isyarat, maupun tulisan seperti di jelaskan dalam kitab as-Syarikat wa ahkamuha fi al-Fiqh al-Islam yang menyatakan:

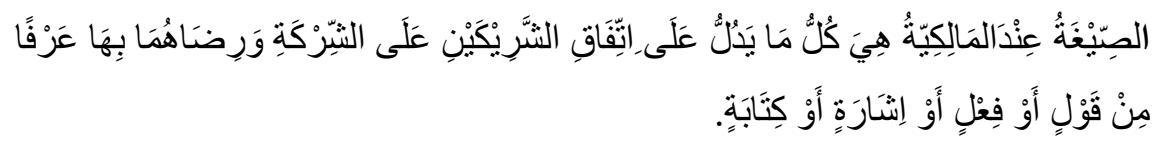

"Shigah menurut malikiyah adalah sesuatu yang menunjukkan kesepakatan dua pihak terhadap suatu kerjasama dan kerelaan keduanya baik perkataan, perbuatan, isyarat atau tulisan" "I4

Untuk menentukan penggunaan akad yang belum jelas dalam praktek tersebut haruslah dilihat dari semua sisi tidak hanya terbatas pada pernyataan saja. Begitu juga tradisi bhubuwen untuk menentukan akad yang digunakan tidak hanya terfokus pada satu bentuk shighat saja melainkan dilihat dari makna dan tujuan sebenarnya akad tesebut.

Tata cara pencatatan transaksi bhubuwen yang dilakukan oleh masyarakat Sukolilo Timur dapat dikatakan telah memenuhi syarat jika ditelaah dari sisi Ekonomi Islam. Walaupun pada dasarnya pencatatan ini hukumnya tidak wajib, tetapi akan menjadi sangat dianjurkan untuk menghindari ada pihak yang wanprestasi atau lalai. Dalam al-Qur'an telah disebutkan dengan jelas mengenai Regulasi mengenai pencatatannya. Di Desa Sukolilo Timur, pencatatan bhubuwen tetap harus dilakukan, yang bertujuan untuk menghindari adanya kesalahan ketika pengembalian buwuh.

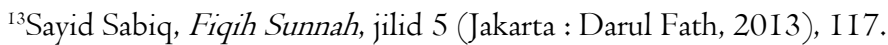

${ }^{14}$ Muhammad Tawiil, al-Syarikat wa Ahkamuha fi al-Fiqh al-Islam, (Beirut: Dar Ibnu Hazm, 2009), 287

90| Al-Iqtishod Volume. I0/No. I/Januari 2022 
Ketika pencatatan dilakukan oleh juru tulis, terdapat pula juru pungut yang fungsi utamanya sebagai saksi pencatatan bhubuwen.

Pencatatan ini memiliki fungsi yang sangat penting yakni sebagai bukti atau penguat transaksi, apabila dalam suatu acara hanya sebatas saksi maka dinilai kurang kuat dan dikhawatirkan akan menimbulkan permasalahan di masa mendatang. Tujuan lainnya juga berfungsi sebagai buku tabungan hutang, agar menghindari salah pencatatan, uang buwuh yang tidak kembali atau nominalnya kurang. Cacatan transaksi yang sama selanjutnya akan dipegang oleh orang yang punya hajatan, orang yang buwuh dan ketua bhubuwen Desa Sukolilo Timur.

Dalam al-Qur'an dijelaskan yang sah menjadi saksi adalah dua orang laki-laki yang beriman, berakal dan telah baligh, begitu pula yang dilakukan dalam penulisan bhubuwen di Desa Sukolilo Timur. Pada saat pencatatan bhubuwen, prosesnya akan disaksikan langsung oleh juru tulis, juru pungut dan orang yang buwuh pada bhubuwen lake'an. Akan tetapi, berbeda pada bhubuwen bine'en semua saksi adalah perempuan. Mengapa demikian, hal ini untuk menghindari perkumpulan yang bukan mahromnya, serta hal ini merujuk kembali pada hukum awal, dikatakan bahwa pencatatan hutang hukumnya tidak wajib, namun tetap dianjurkan bagi orang-orang yang bermuamalah dengan tidak tunai (hutang piutang), hukum wajib pencatatan hutang juga telah dinasakh dalam surat al-Baqarah 283 yaitu:

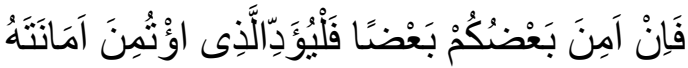

"apabila sebagian kamu mempercayai sebagian yang lain maka hendaklah yang dipercayai itu menunaikan amanahnya"."IS

Tujuan lain dari adanya saksi juga dijelaskan pada surah al-Baqarah ayat 282 yakni apabila saksi pertama lupa maka saksi lain bisa mengingatkannya, begitu pula sebaliknya. Selain adanya saksi pada pencatatan bhubuwen, terdapat pula tiga macam buku catatan yaitu yang dipegang oleh yang mengadakan hajatan, orang yang buwuh, serta ketua bhubuwen (agen). Sehingga terdapat dua macam saksi yang menjadi bukti

\footnotetext{
${ }^{15}$ Departemen Agama, al-Quran dan Terjemahannya, (Jakarta: PT. Hati emas, 2013), 49
}

Volume. I0/No. I/Januari 2022 A1-Iqtishod|9I 
Tinjauan Ekonomi Islam Pada ...

atau penguat ketika dimasa yang akan datang ada pihak yang lupa, lalai atau wanprestasi, yaitu saksi manusia dan saksi dalam bentuk catatan.

Dalam surah al-Baqarah ayat 282 telah disebutkan mengenai hukum hutang piutang. Dalam tafsir al-Misbah dijelaskan pula bahwa, dalam melakukan transaksi utang piutang terdapat dua nasehat pokok, pertama "waktu yang ditentukan", hal ini berarti ketika melakukan transaksi hutang piutang harus ditentukan pula waktu atau masa pelunasannya, kedua "menulis transaksi hutang" untuk menghindari adanya pihak yang lupa atau lalai. ${ }^{16}$ Akan tetapi suatu akad hutang tidak dapat batal apabila tidak menentukan penetapan waktu karena bukan termasuk rukun akad.

Dalam pelaksanaannya, tradisi bhubuwen ada jangka waktu yang telah ditentukan untuk membayar hutang buwuh, karena pelaksanaannya mengikuti aturan yang telah ada dalam hadits, yaitu yang menjelaskan bahwa dilarang berhutang dengan tidak ada waktu pembayarannya. Pelaksanaan tradisi bhubuwen yang menentukan waktu pembayaran adalah pihak yang memiliki hajat. Ketika seseorang mengadakan hajatan maka pada saat itulah waktu pembayaran hutangnya. Jangka waktu pembayaran hutang atau waktu untuk mengadakan hajatan tersebut sesuai dengan hukum urf yang telah ditetapkan sebelumnya. Waktu pembayaran bhubuwen secara umum khususnya di Desa Sukolilo Timur, selama itu tidak menghalalkan yang haram maupun sebaliknya, maka sah saja dilakukan pembayaran bhubuwen dengan jangka waktu yang ditentukan oleh adat kebiasaan pengembalian buwuh.

\section{E. Simpulan}

Berdasarkan hasil penelitian dan uraian tentang bagaimana praktik tradisi bhubuwen di desa Sukolilo Timur dan pandangan ekonomi Islam terhadap tradisi tersebut maka dapat disimpulkan sebagai berikut:

I. Bhubuwen adalah praktek Sumbang menyumbang berupa uang yang terdapat dalam tradisi to'oto' dan remoh. Sumbangan tersebut bersifat hutang dan harus

\footnotetext{
${ }^{16}$ M. Quraish Shihab, Tafsir al-Misbah, (Jakarta: Lentera Hati 2002), hlm. 732
} 
dikembalikan dengan ukuran yang sama, sebelum mengadakan to'oto' dan bhubuwen ada proses yang harus disiapkan. Persiapan to oto' sama seperti persiapan hajatan biasanya jika itu hajatan pernikahan maka mempersiapkan apa yang dibutuhkan dalam pernikahan. Sedangkan persiapan bhubuwen ada proses panjang yang harus dikerjakan. Pertama perizinan acara ke muspika. Kedua, penyebaran undangan. Ketiga, pembayaran buwuh. Empat, juru tulis dan pencatatan uang buwuh.

2. Dalam prespektif ekonomi Islam akad yang digunakan dalam transaksi bhubuwen adalah akad qardh (hutang piutang) penetapan itu berdasarkan rukun dan syarat maupun ketentuan yang harus ada dalam akad qardh, tradisi bhubuwen sudah memenuhi kriteria akad hutang. Jika penyumbang meninggal maka akad berubah menjadi hibah dengan dasar urf. Begitu juga Pencatatan bhubuwen sudah sesuai dengan tatacara pencatatan dalam ekonomi Islam.

\section{F. Daftar Pustaka}

Abdullah Muhammad, Abu.Sunan Ibnu Majah.Beirut: Dar al-Kotob al-Ilmiyah.

Abdullah, Boedi. Ahmad, Beni. Metodologi Penelitian Ekonomi Islam Muamalah. Cet. ke-I. Bandung: CV. Pustaka Setia, 2014.

Abi Bakr Ibnu Muhammad al-Husaini, Taqiy al-Din. Kifayahal-Akhyar:Surabaya: Maktabah Balai Buku.

Abu Ismail, Imaduddin. Terjemah Singkat Tafsir Ibnu Katsier. Jilid I. Surabaya: PT Bina Ilmu.

Ahmad Azhar, Basyir.Asas-asas Hukum MuamalatHukum Perdata Islam. Yogyakarta: UII Press. 2004.

Angga Raza, Diah. Makna Tradisi Buwuh dalam Acara Pernikahan di Desa Turirejo Kabupaten Kedamean Kecamatan Gresik. UIN Sunan Ampel Surabaya. 2014.

Azizi Muhammad Azzam, Abdul. Nidhom al-Mu'amalah fi al-Fiqh al-Islamiy.Jakarta: Amzah.

Azwar, Saifuddin. Metode Penelitian. Yogyakarta: Pustaka Pelajar. 2015.

Badan Pusat Statistik Kabupaten Bangkalan Kecamatan Labang Tahun 2015 dalam Katalog.

Berger. Teknik Praktif Riset Komunikasi. Jakarta: Kencana Media Prenada Grub. 2012.

bin Ismail as-Shan'ani,Muhammad.Subul as-Salam Sarh Bulugh al-Marom, Beirut: Dar al-Kotob alIlmiyah. 2006.

Bungin, Burhan. Penelitian Kualitatif. Jakarta: Kencana. 2007.

Volume. I0/No. I/Januari 2022 A1-Iqtishod|93 
Tinjauan Ekonomi Islam Pada ...

Dawud Al-Sijistan, Abu. Sunan Abi Dawud. Beirut: Dar al-Kotob al-Ilmiyah. 2013.

Departemen Agama.al-Quran dan Terjemahannya. Jakarta: PT. Hati Emas. 2013.

Departemen Pendidikan Nasional.Kamus Besar Bahasa Indonesia (KBBI). Jakarta: PT Gramedia. 2008.

Dewi, Gemala dkk.Hukum Perikatan Islam di Indonesia. Jakarta: Kencana. 2005.

Effendi, Satria. M.Zein.Ushul Fiqh. Jakarta: Kencana. 2005.

Farid Muhammad Washil, Nasr. Aziz Muhammad Azzam, Abdul. Qawaid Fiqhiyyah.Jakarta: Amzah. 2013.

Ghazaly, Abdurrahman.Ihsan, Ghufron.Fiqh Muamalat. Jakarta: Kencana. 2010.

Hamdani.Post Tradisionalisme Islam. BLD Departemen Agama RI. 2008.

Hartanto. Aziz, Arnicun.Ilmu Sosial Dasat. Jakarta: Bumi Aksara. 2004.

Hasan Ayyub, Syaikh. Fiqh al-Mu'amalah al-Maliyah fi al-Islam. Kairo: Dar As-Salam. 2006.

Iska, Syukri. System Perbankan Syariah di Indonesia. Yogyakarta: Fajar Media Press. 2012.

Ismail al-Bukhari, Muhammad.Sahih al-Bukhari, Beirut: Dar al-Kotob al-Ilmiyah. 2015.

Jurnal Karsa, Zainal Abidin, Holilur Rahman, Tradisi Bhubuwan Sebagai Model Investasi di Madura. Karsa Ekonomi Islam. 2013. Vol. 2I No. I.

Jurnal Muzakkir S. Regulasi Hutang Piutang dalam Tinjauan Ekonomi Islam, Telaah Terhadap Surat al-Baqarah Ayat 28. Iqtishaduna Jurnal Ekonomi Islam. 20I4. Vol.5 No.I.

Karim, Adiwarman. Analisis Fiqih dan Keuangan. Jakarta: Rajagrafindo Persada. 2013.

Kasmir.Bank dan Lembaga Keuangan Lainnya. Jakarta: Rajagrafindo Persada. 2013.

Kuncoroningrat.Sejarah Kebudayaan Indonesia.Yogyakarta: Jambatan. 1954.

Laeli Nurmandriani, Rhespa. Solidaritas Pola Sumbang-menyumbang Masyarakat Desa (Study Praktik Sumbang-menyumbang dalam Acara Hajatan Padukuhan Kepuhan, Desa Argorejo, Kecamatan Sedayu, Bantul Yogjakarta. UIN Sunan Kalijaga Yogyakarta. 2015.

Mandani.Fiqih Ekonomi Syariah Fiqih Muamalah. Jakarta: Kencana. 2012.

Moleong, Lexy j. Metodologi Penelitian Kualitatif. Cet ke-2I. Bandung: Rosda. 2005.

Muhammad Amin al-Kurdi, Syaikh. Tanwir al-Qulub fi Mu'amalati allamu al- Ghuyub. Surabaya: Al-Hidayah.

Muhammad Nawawi bin Umar al-Jawi, Syaikh.Qut al-Habib al-Gharib. Beirut: Dar al-Kotob alIlmiyah. 2003.

Muhammad Syatha al-Dimyati, Sayyid.I'anah at-Thalibin. Semarang: Toha Putra.

Munir, Misbahul.Implementasi Prudential Banking dalam Perbankan Syariah. Malang: UIN Malang Press. 2009. 
Prastowo, Andi. Menguasai Teknik-teknik Koleksi Data Penelitian Kualitatif. Yogyakarta: Diva Press. 2010.

Rasjid, Sulaiman.Fiqh Islam Hukum Fiqh Islam.Bandung: Sinar Baru Algensindo. 201 I.

Rifa'I, Mien Ahmad.Manusia Madura. Yogyakarta: Pilar Media. 2007.

Shihab, M. Quraish. Tafsir Al-Misbah. Jakarta: Lentera Hati. 2002.

Suhendi, Hendi.Fiqh Muamalah. Jakarta: Rajawali Pers. 2010.

Syaodih Sukmadinata, Nana. Metode Penelitian Pendidikan. Bandung: PT Remaja Rosdakarya. 2005.

Tanwiil, Muhammad.as-Syarikat wa Ahkamuha fi al-Fiqh al-Islam. Beirut: Dar Ibnu Hazm. 2009.

Wahab Khallaf, Abdul. Ilmu Ushul al-Fiqh Kaidah Hukum Islam. Jakarta: Pustaka Amani. 2003.

Zainal, Yusuf. Ahmad Saebani, Beni. Pengantar Sistem Sosial Budaya. Bandung: Pustaka Setia. 2014.

Volume. I0/No. I/Januari 2022 Al-Iqtishod|95 